\title{
ELASTOMER SPACERS IN FIRE CONDITIONS
}

\author{
Paweł ROSZKOWSKI, Bartłomiej SĘDŁAK ${ }^{1}$, Paweł SULIK \\ Instytut Techniki Budowlanej, Warszawa, Poland
}

\begin{abstract}
In the paper, fire resistance of linear joints seal made of elastomer spacers under standard fire conditions, and thermal degradation range of EPDM elastomeric spacers are investigated. The geometry of elastomer spacer joints is important not only for their load capacity under normal conditions - thickness, width, and cavity depth can also influence fire resistance performance. Linear joints of different thicknesses and widths have been tested. The fire insulation and fire integrity were verified for various arrangements. Relatively low thermal degradation rates have been measured, given that EPDM is a combustible material.
\end{abstract}

Keywords: fire resistance, fire integrity, fire insulation, elastomer spacer, EPDM, thermal degradation, linear joint seal

\section{INTRODUCTION}

The major task of elastomer spacer is its deformation under the influence of the present vertical and horizontal forces, and the transfer of these loads to the support construction, with the simultaneous reduction of the influence of the horizontal forces and rotates from the supporting part. In most cases, spacers are used in the connection of monolithic elements. On a market we can find a couple of producers of elastomer spacers. Moreover, elastomer spacers filed gaps are a linear joint seal. Linear joints should be characterised by a relation of length to width of at least 10:1. Standard EN 1366-4 [1] linear joint seal define as a system designed to maintain the fire separating function and, if relevant, to accommodate a specified degree of movement within the linear joint.

\footnotetext{
${ }^{1}$ Corresponding author: Instytut Techniki Budowlanej, Zakład Badań Ogniowych, Filtrowa st 1 , 00-611 Warszawa, Poland, e-mail: b.sedlak@itb.pl, tel.+48225664494
} 
Because of their use in residential or production or storage buildings they should meet fire safety requirements.

The paper presents two problems related to behaviour in fire:

- fire resistance (verified by the criteria: fire insulation and fire integrity) of linear joint seals made of elastomeric spacers in standard fire conditions (verification according to the research standard),

- extent of thermal degradation of elastomer spacer that fills linear joints (nonstandard method).

Fire resistance requirements are directly attributable to Polish regulations [2], but the extent of spacer degradation after fire is required for the selection of elastomeric spacers.

Other types of linear joint seals and their behaviour under fire conditions were discussed in articles [3-8].

\section{METHODOLOGY OF FIRE TEST}

The fire tests were conducted at the Fire Research Laboratory of the Institute of Building Technology (ITB) in 2013. One type of elastomer spacers of different thicknesses and widths were evaluated.

Verification of fire integrity and fire integrity was carried out in accordance with EN 1366-4 [2]. Verification of the extent of thermal degradation of elastomeric spacers is an abnormal method. It was conducted on the basis of the internal ITB procedure.

\subsection{Test condition}

Fire resistance test was conducted from one side of test specimen for 2 hours with a standard temperature-time curve, in accordance with EN 1363-1 [9], see equation (1).

$$
\mathrm{T}=660 \cdot[1-0,687 \cdot \exp (-0,32 \cdot \mathrm{t})-0,313 \cdot \exp (-3,8 \cdot \mathrm{t})]+20
$$

Where:

$\mathrm{T}$ is the mean furnace temperature in degrees Celsius;

$\mathrm{t}$ is the time form the start of the test in minutes.

Test equipment and test conditions are given in standard EN 1363-1 [9].

Horizontal joints filled with elastomer washers are executed in vertical supporting construction (orientation of joints according to EN 1366-4 [1] point $13.1-$ - "C". 


\subsection{Test material}

Tested material were elastomer spacer.

Elastomer spacers were components made of vulcanised ethylene-propylenediene natural rubber (ethylene propylene diene monomer, EPDM).

Tested Spacers were characterised by a transverse modulus of elasticity $\mathrm{G}_{\mathrm{g}}=0.9 \mathrm{MPa} \pm 0.15 \mathrm{MPa}$ (declared by the manufacturer). Information about the dimensions of the spacers and their configuration you can find in point Test specimen.

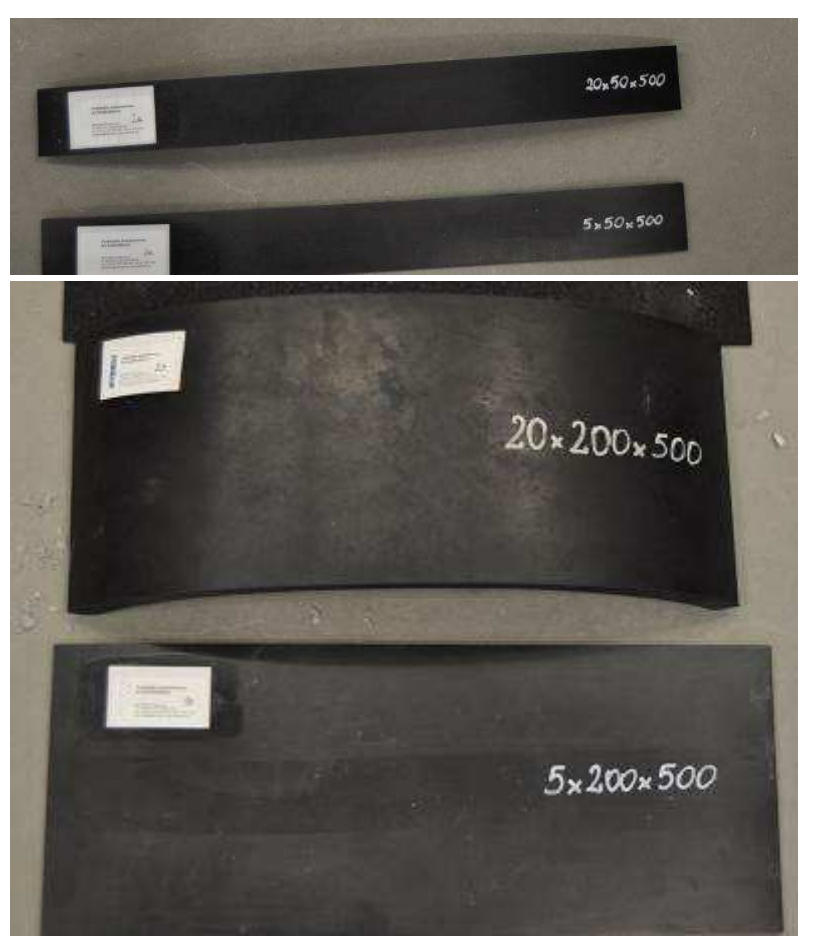

Fig. 1. Elastomer spacers used for the fire test

\subsection{Test specimen}

The test verified a total of 12 linear joint seals, four of which were analysed as part of this paper. A single joint was filled with two spacers placed next to each other, forming a $1000 \mathrm{~mm}$ long joint. Arrangement and cross-sections of the analysed joints are presented in Fig. 2 and 3. 


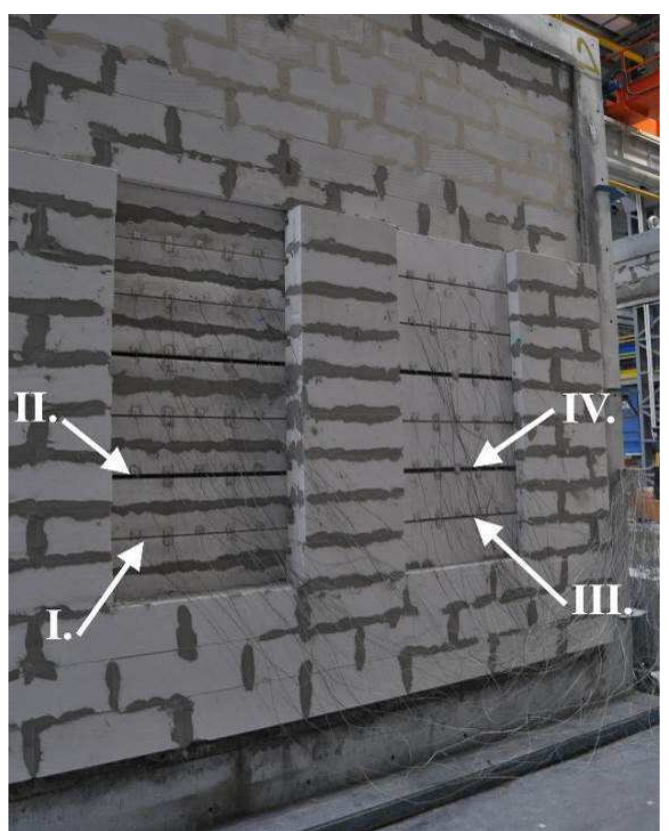

Fig. 2. View of test specimen and arrangement of linear joint seals from unexposed side

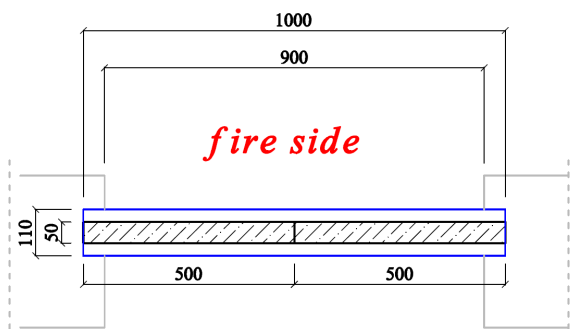

I. and II.

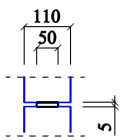

I.

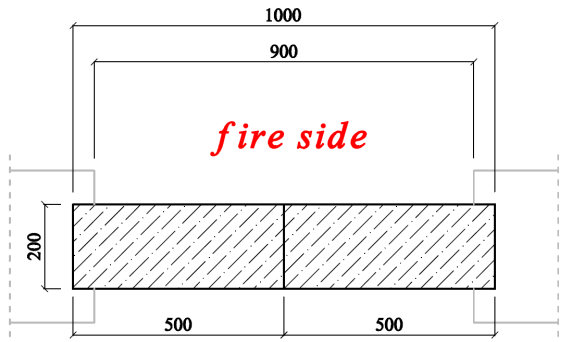

III. and IV.

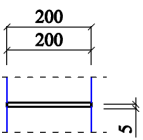

III.

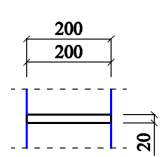

IV.

Fig. 3. Cross-sections of the liner joint seals

The seals were made of EPDM-based vulcanised rubber. The test included joints with minimum $(5 \mathrm{~mm})$ and maximum $(20 \mathrm{~mm})$ width and with minimum $(50 \mathrm{~mm})$ and maximum $(200 \mathrm{~mm})$ depth for each case. Seals with the minimum depth were placed symmetrically inside the supporting construction with a thickness of $110 \mathrm{~mm}$, while the joints with the maximum depth completely 
filled the supporting construction with the thickness of $200 \mathrm{~mm}$. In both cases, the supporting construction was made of autoclaved cellular concrete blocks. Linear joint seals had the following dimensions (width $\times$ depth $\times$ length):

- $5 \times 50 \times 1000 \mathrm{~mm}-$ a joint with minimum width, installed in the supporting construction with the minimum thickness, marked on diagrams as Jmin_Cmin (figure 2 and 3, the position I.),

- $20 \times 50 \times 1000 \mathrm{~mm}-$ a joint with maximum width, installed in the supporting construction with the minimum thickness, marked on diagrams as Jmax_Cmin (figure 2 and 3, the position II.),

- $5 \times 200 \times 1000 \mathrm{~mm}-$ a joint with minimum width, installed in the supporting construction with the maximum thickness, marked on diagrams as Jmin_Cmax (figure 2 and 3, the position III.),

- $20 \times 200 \times 1000 \mathrm{~mm}-$ a joint with a maximum width, installed in the supporting construction with the maximum thickness, marked on diagrams as J_Cmax (figure 2 and 3, the position IV.).

Seals with the same width were installed at the same height in the supporting construction.

The study compared average temperature rises on the surface of the joint seal, which was measured in each component by means of 7 thermocouples installed with a special glue. Thermocouples were located in points specified in EN 13664:2006+A1:2010 [3], in accordance with Figure 3. The comparison was made for two cases - an average rise of temperature recorded by all thermocouples and the average rise of temperature recorded by thermocouples No 2, 3, 5 and 6, located at the distance of $20 \mathrm{~mm}$ from the horizontal joint edge.

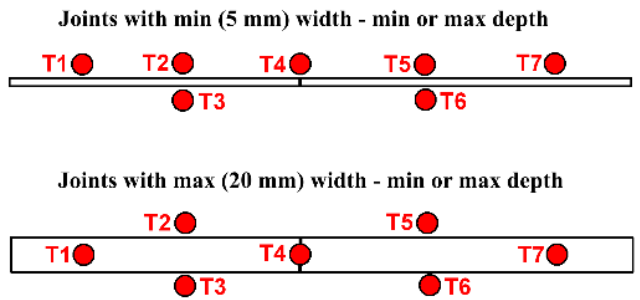

Fig. 4. Locations of thermocouples - unexposed side of the linear joint seal

\section{TEST RESULTS}

\subsection{Fire insulation criterion}

Fire insulation (I) of the linear joint seals is assessed on the basis of temperature rises on the unexposed surface of the test specimen (the average temperature rise is limited to $140^{\circ} \mathrm{C}$ above the initial average temperature, while the maximum 
temperature rise at any point in the tested partition is limited to $180^{\circ} \mathrm{C}$ above the initial temperature).

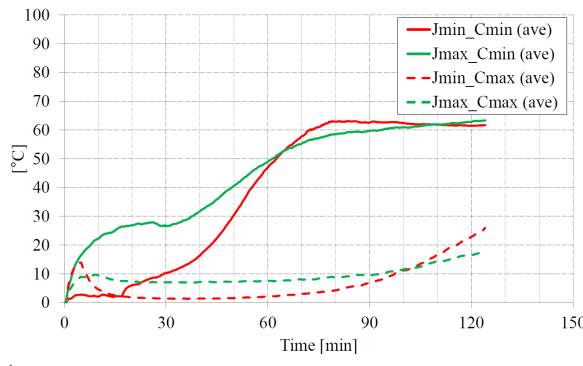

a)

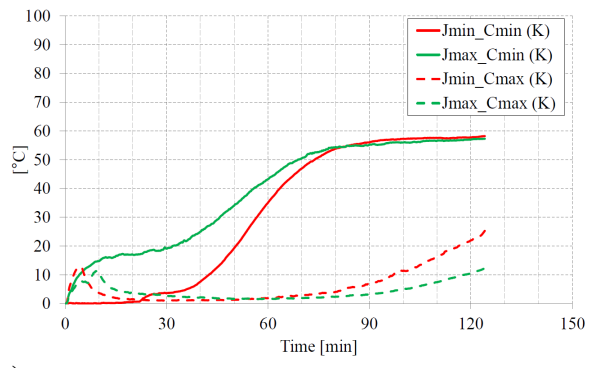

b)

Fig. 5. The temperature rises on unexposed side of linear join seals: (a) the average of the thermocouples 1-7; (b) the average of the thermocouples 2, 3, 5, 6

Figures $5 \mathrm{a}$ and $5 \mathrm{~b}$ present the average rises of temperature at the surface of all joint seals. In the case of Figure 5a, the average was determined based on temperature rises recorded by all thermocouples located at the specific joint seal, and in the case of Figure 5b, the average was determined based on measurements of thermocouples No 2, 3, 5 and 6. Linear joint seals with minimum thickness are marked in Figures $5 \mathrm{a}$ and $5 \mathrm{~b}$ with red colour and those with maximum width with green colour. The solid line marks linear joint seals in the supporting construction with minimum thickness and the dashed line denotes linear joint seals in supporting construction with maximum width.

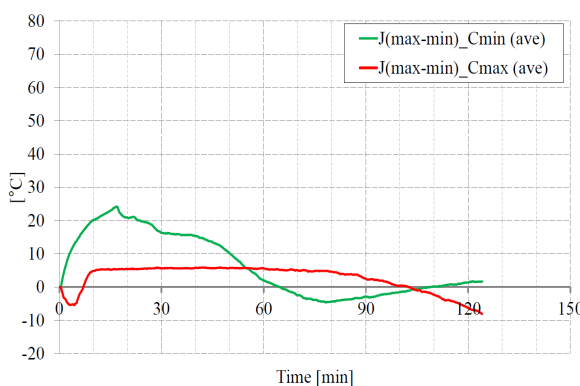

a)

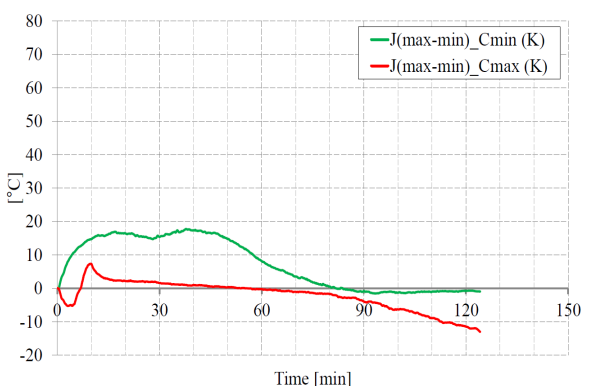

b)

Fig. 6. The difference between temperature rises at unexposed surface of linear joint seals with maximum and minimum width: (a) the average of the thermocouples No 1-7; (b) the average of the thermocouples No 2, 3, 5, 6

Figures $6 \mathrm{a}$ and $6 \mathrm{~b}$ present the differences between the average rises of temperature at the surfaces of joints with maximum width and surfaces of joints with minimum width. In the case of Figure 6a, the average was determined based on temperature rises recorded by all thermocouples located at the specific joint, and in the case of Figure $6 \mathrm{~b}$, the average was determined based on 
measurements of thermocouples No 2, 3, 5 and 6. The solid green line marks linear joint seals in the supporting construction with minimum thickness and the solid red line denotes linear joint seals in supporting construction with maximum width.

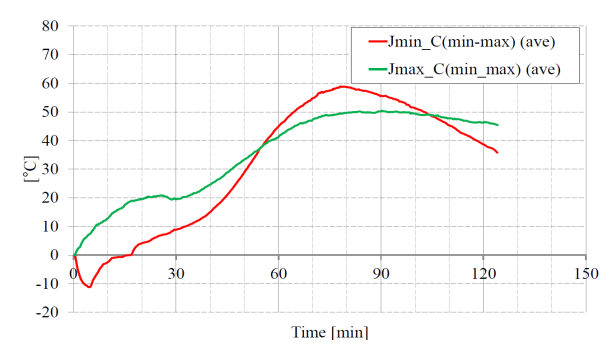

a)

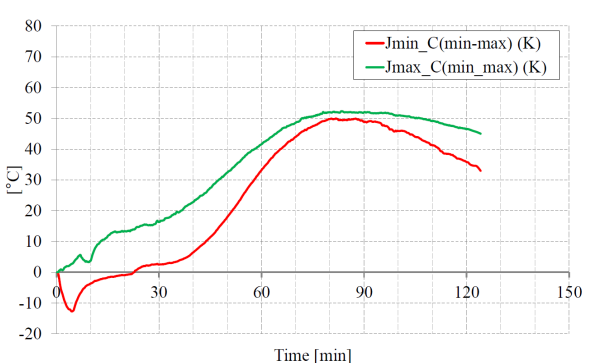

b)

Fig. 7. The difference between temperature rises at unexposed surface of linear joint seals in the supporting construction with minimum and maximum width: (a) the average of the thermocouples No 1-7; (b) the average of the thermocouples No 2, 3, 5, 6

Figures $7 \mathrm{a}$ and $7 \mathrm{~b}$ present the differences between the average rises of temperature at the surfaces of joints in the supporting construction with minimum width and surfaces of joints in the supporting construction with maximum thickness. In the case of Figure $7 \mathrm{a}$, the average was determined based on temperature rises recorded by all thermocouples located at the specific joint, and in the case of Figure $7 \mathrm{~b}$, the average was determined based on measurements of thermocouples No 2, 3, 5 and 6. Linear joint seals with minimum width are marked in Figures 7 with red colour and those with maximum width with green colour.

By analysing the diagrams presented in Figures 5-7, one can see that the width of a specific joint has no significant impact on properties related to fire insulation. In the case of joint seals installed in the supporting construction with minimum thickness, the greatest difference in measured temperature occurred during the initial stage of testing (at ca. $17^{\text {th }}$ minute, $23^{\circ} \mathrm{C}$ of temperature difference between joint seals with the maximum and minimum width), and during the final stage of testing the difference was negligible (ca. $1^{\circ} \mathrm{C}$ in the last minute of the test). In the case of the supporting construction with maximum thickness, the difference between the temperature at unheated surfaces of linear joint seals with maximum and minimum width was insignificant at any time ca. $10^{\circ} \mathrm{C}$ in the last minute of the test.

As presented in Figure $7 \mathrm{~b}$, the fire insulation of the seal was more affected by its depth - the difference between temperatures recorded at the joint seals in the supporting construction with the thickness of $110 \mathrm{~mm}$ and joint seals in supporting construction with the thickness of $200 \mathrm{~mm}$ reached $50^{\circ} \mathrm{C}$ in the 
$80^{\text {th }}$ minute of the test. In the last minute of the test, this difference was ca. $35^{\circ} \mathrm{C}$ for joints with minimum thickness and ca. $45^{\circ} \mathrm{C}$ for joints with maximum thickness.

\subsection{Fire integrity criterion}

Fire integrity (E) of the assessed on the basis of three aspects: ignition of the cotton pad, sustained flaming on the unexposed surface or gaps exceeding the permissible dimensions; the cotton pad inflammation criterion is not taken into account if the element is classified only for fire integrity without considering the fire insulation classification.

During the two-hour test the fire integrity criterion was not exceeded. The view of the test specimen during the test is shown in Figure 8.
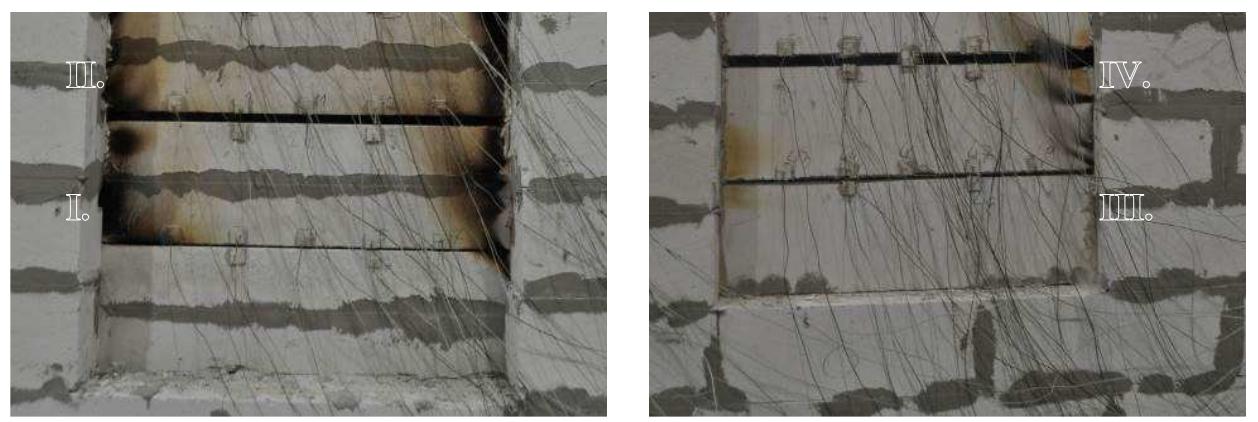

Fig. 8. Linear joint seal during the test $(\mathrm{t}=120 \mathrm{~min})$

\subsection{Thermal degradation}

After the test, the extent of degradation was measured. Measurements of one spacer were measured in at least four positions. Measurements were not made at the ends of the joints, where in some cases the pads were heated, resulting from inaccurate sealing between the joint seal and the supporting construction. The view of the elastomer spacers after the test and the measurements are shown in figure 9.

Based on the test, it is noted that the cavity depth of the spacers has a significant effect on their extent of degradation. The thickness of the spacer also affects the extent of degradation, but the effect of degradation is smaller. The presented measurements are used to determine the average degradation rate of the spacers. The average degradation rate was $0.1-0.5 \mathrm{~mm} / \mathrm{min}$ (depending on linear joint seal width or linear joint seal depth or cavity depth).

It is difficult to estimate the impact of the supporting construction made of autoclaved cellular concrete, on the extent of degradation. The results of tests and behaviour on being exposed to high temperatures are presented in [10]. 


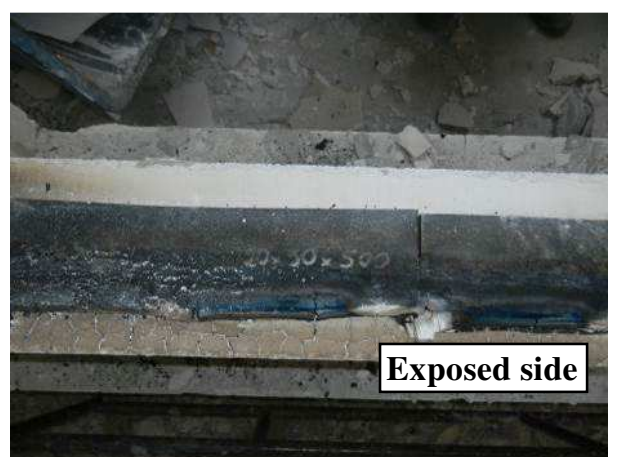

Linear joint seal No. II

extent of thermal degradation - 21,8 mm

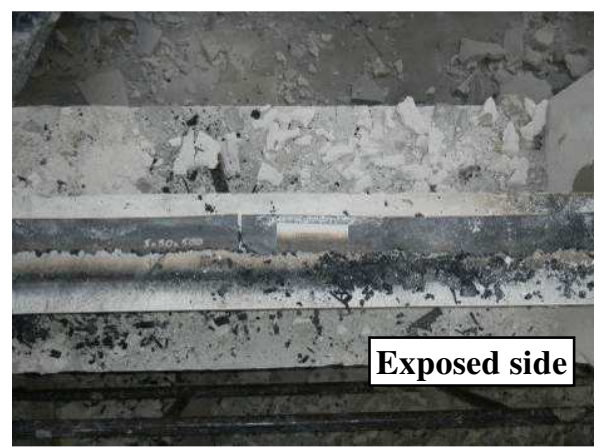

Linear joint seal No. I

extent of thermal degradation - $16 \mathrm{~mm}$

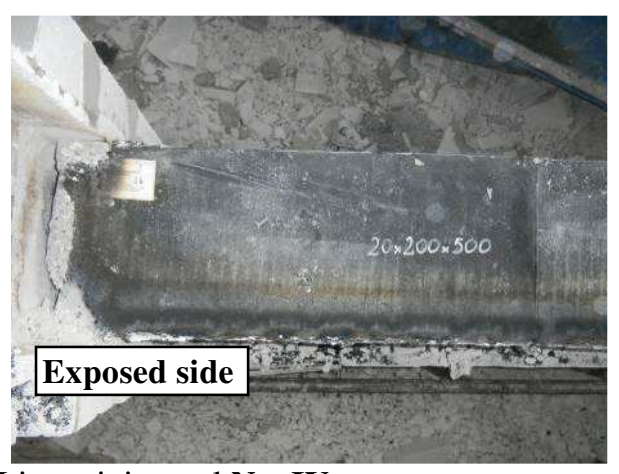

Linear joint seal No. IV

extent of thermal degradation $-45 \mathrm{~mm}$

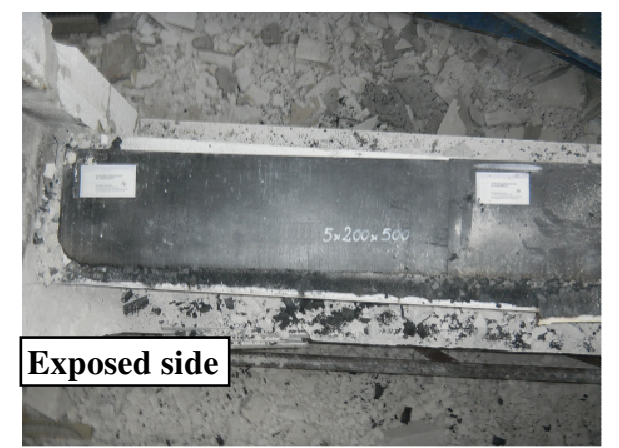

Linear joint seal No. III

extent of thermal degradation $-52,7 \mathrm{~mm}$

Fig. 9. Elastomer spacers after the test

\section{CONCLUSIONS}

- The test has shown that dimensions of elastomer spacers are important not only when determining their load capacity under normal conditions thickness, width, and cavity depth can influence fire resistance performance.

- Additional thermal degradation measurements are important when selecting the minimum dimensions of the spacers to ensure sufficient loadbearing capacity and fire safety.

- It would be expected that the material with class E reaction to fire [11] would degrade faster than observed. The fire resistance test show that the elastomer spacers (EPDM) degrade only on their exposed surface and the average degradation rate is $0.1-0.5 \mathrm{~mm} / \mathrm{min}$ (depending on cavity depth and joint seal width.) 
- It was observed that the width of a specific joint has no significant impact on properties related to fire insulation of the linear joint seal made of EPDM spacers.

- In the case of the supporting construction with minimum thickness (minimum depth), the greatest difference in measured temperature occurred during the initial stage of testing, and during the final stage of testing the difference was negligible.

- In the case of the supporting construction with maximum thickness (maximum depth), the difference between the temperature at unheated surfaces of linear joint seals with maximum and minimum width was insignificant at any time,

- It was observed that the depth (and/or cavity depth) of the linear joint seal has a greater impact than the width of the linear joint seal made of EPDM spacer.

- The fire integrity criterion was not exceeded in all cases during the two-hour fire resistance test.

\section{REFERENCES}

1. EN 1366-4:2006+A1:2010. Fire resistance tests for service installations Part 4: Linear joint seals.

2. Rozporządzenie Ministra Rolnictwa i Gospodarki Żywnościowej z dnia 7 października 1997 r. W sprawie warunków technicznych, jakim powinny odpowiadać budynki rolnicze i ich usytuowanie (Dz. Ust. Nr 132 poz. 877 z późniejszymi zmianami).

3. Sędłak B.: Badania odporności ogniowej przeszklonych ścian osłonowych. Cz. 1, Świat Szkła, 9, (2012), 52-54.

4. Sędłak B.: Badania odporności ogniowej przeszklonych ścian osłonowych. Cz. 2, Świat Szkła, 10, (2012), 53-58, 60

5. Sędłak B. Badania odporności ogniowej przeszklonych ścian osłonowych wg nowego wydania normy PN-EN 1364-3, Świat Szkła, 7-8, (2014), 49-53.

6. Turkowski P., Roszkowski P.: Odporność ogniowa żelbetowych balkonów wspornikowych $z$ tacznikami zbrojeniowymi, Materiały Budowlane, 7, (2014), 23 - 24.

7. Roszkowski P., Sędłak B., Sulik P. Fire resistance of linear joint seals with movement capability - results comparison, $2^{\mathrm{ND}}$ International Fire Safty Symposium 2017 Napoli, Italy, 2017, pp. 289-296. 
8. G. Camino and S. Lomakin, Intumescent materials, Fire Retardant Materials, A. R. Horrocks and D. Price, Eds. Woodhead Publishing Limited, 2001, pp. 318-335.

9. EN 1363-1:2012 Fire resistance tests - Part 1: General Requirements.

10. G. Zapotoczna-Sytek, P. Sulik, G. Woźniak, and M. Abramowicz, Przegrody budowlane wykonane $z$ aut.oklawizowanego betonu komórkowego (ABK), a bezpieczeństwo pożarowe, in Dni betonu: Tradycja i nowoczesność. 8 Konferencja, 2014, pp. 803-814.

11. EN 13501-1:2007+A1:2009 Fire classification of construction products and buildings elements - Part 1: Classification using data from reaction to fire test.

\section{PODKŁADKI ELASTOMEROWE W WARUNKACH POŻAROWYCH}

\section{Streszczenie}

W artykule analizowano odporność ogniową uszczelnień złączy liniowych wykonanych z podkładek elastomerowych EPDM. Geometria podkładek elastomerowych jest ważna nie tylko pod względem ich nośności w warunkach normalnych - grubość, szerokość i głębokość zagłębienia podkładek, mają również wpływ na odporność ogniową. $\mathrm{W}$ artykule przetestowano uszczelnienia złączy liniowych o różnych grubościach i szerokościach. W opisywanym badaniu sprawdzano izolacyjność ogniową i szczelność ogniową dla różnych wariantów. $\mathrm{Z}$ dokonanych pomiarów wynikają stosunkowo małe prędkości degradacji cieplnej, biorąc pod uwagę, że EPDM jest materiałem palnym.

Słowa kluczowe: odporność ogniowa, szczelność ogniowa, izolacyjność ogniowa, podkładka elastomerowa, EPDM, degradacja termiczna, uszczelnienie złącza liniowego

Editor received the manuscript: 19.07.2017 